\title{
Phytostabilisation on post-flotation sediment waste: mobility of heavy metals and stimulation of biochemical processes by mineral-organic mixtures
}

\author{
Krzysztof Gondek $^{1}$ (D) $\cdot$ Monika Mierzwa-Hersztek ${ }^{1,2}$ (I) $\cdot$ Michał Kopeć $^{1}$ (D) $\cdot$ Tomasz Bajda $^{2}$ (D)
}

Received: 31 October 2019 / Accepted: 27 April 2020 / Published online: 26 May 2020

(C) The Author(s) 2020

\begin{abstract}
Purpose The study aimed to determine the effect of the addition of innovative combinations of organic-mineral mixtures obtained from biochar (BC), zeolite (Z), soil (S), poultry litter (PL), and slurry (SL) to post-flotation sediment (PFS) on (i) heavy metal mobility, (ii) heavy metal accumulation in willow, and (iii) PFS respiratory activity.

Materials and methods The tests were carried out under laboratory conditions in containers with $500 \mathrm{~g}$ of PFS, to which $1 \%$ (w/w) of organic-mineral mixtures were added. Willow was grown for 90 days on substrates with the addition of organic and mineral mixtures. Results and discussion The addition of mixtures $\mathrm{BC}+\mathrm{Z}+\mathrm{S}+\mathrm{PL}$ and $\mathrm{BC}+\mathrm{Z}+\mathrm{S}+\mathrm{SL}$ to PFS significantly reduced the $\mathrm{pH}$ to, respectively, 7.12 and 7.02. This can be attributed to the release of the hydrogen load combined with organic anions deriving from the mineralisation of organic materials and the nitrification process. The addition of $\mathrm{BC}+\mathrm{Z}$ and $\mathrm{BC}+\mathrm{Z}+\mathrm{S}$ mixtures to PFS reduced the content of $\mathrm{Zn}-\mathrm{H}_{2} \mathrm{O}$ by $65 \%, \mathrm{Cd}-\mathrm{H}_{2} \mathrm{O}$ by $48 \%$, and $\mathrm{Ni}-\mathrm{H}_{2} \mathrm{O}$ by $30 \%$. The addition of $\mathrm{BC}+\mathrm{Z}+\mathrm{S}+\mathrm{PL}$ and $\mathrm{BC}+\mathrm{Z}+$ $\mathrm{S}+\mathrm{PL}$ mixtures to PFS increased the content of water-extracted Pb, respectively, 40 and over 60 times. The content of bioavailable heavy metals (extraction with $1 \mathrm{M} \mathrm{NH}_{4} \mathrm{NO}_{3}$ ) in PFS was comparable in all treatments to which mixtures were added. Altered mobility of heavy metal ions may be associated with a change of substrate properties, including redox potential, $\mathrm{pH}$ value, as well as the introduction into the soil of materials with significantly developed sorption surfaces. In the first 2 weeks of incubation of mixtures with PFS, respiratory activity was very low, except for that in $\mathrm{BC}+\mathrm{Z}+\mathrm{S}+\mathrm{PL}$ and $\mathrm{BC}+\mathrm{Z}+\mathrm{S}+\mathrm{SL}$ treatments. In these treatments, oxygen consumption was more than 50 times higher compared to the control treatment and more than 10 times higher in relation to $\mathrm{BC}+\mathrm{Z}$ and $\mathrm{BC}+\mathrm{Z}+\mathrm{S}$ treatments.

Conclusions The mixtures of $\mathrm{BC}+\mathrm{Z}$ and $\mathrm{BC}+\mathrm{Z}+\mathrm{S}$ effectively reduced the content of water-extracted heavy metals in PFS. $\mathrm{BC}+\mathrm{Z}+\mathrm{S}+\mathrm{PL}$ and $\mathrm{BC}+\mathrm{Z}+\mathrm{S}+\mathrm{PL}$ mixtures were not effective in reducing water-extracted mobile heavy metals in PFS. The introduction into PFS of mixtures partially composed of biologically unstable materials (PL, SL) increased the biochemical activity measured by respiratory activity and reduced biomass increment of willow aerial parts. The adverse response of willow to the introduction of mixtures with poultry litter or slurry into PFS indicates the need to verify the amount of these materials in the mixtures or to stabilise them by biological or thermal processes.
\end{abstract}

Keywords Bioaccumulation $\cdot$ Biochar $\cdot$ Post-flotation sediment $\cdot$ Poultry litter $\cdot$ Slurry $\cdot$ Zeolite

Responsible editor: Tomas Matys Grygar

Monika Mierzwa-Hersztek

monika6_mierzwa@wp.pl

1 Department of Agricultural and Environmental Chemistry, University of Agriculture in Krakow, al. Mickiewicza 21, 31-120 Krakow, Poland

2 Faculty of Geology, Geophysics and Environmental Protection, Department of Mineralogy, Petrography and Geochemistry, AGH University of Science and Technology, al. Mickiewicza 30, 30-059 Krakow, Poland

\section{Introduction}

Improper transport, processing, and storage of waste materials, including post-flotation sediments, pose a threat to the environment and human health. It results from the possible presence of various contaminants in these materials, which are toxic to living organisms. It is, therefore, necessary to develop techniques for stabilising post-flotation sediments so that the contaminants accumulated in them, including heavy metals, would not pose a risk to living organisms. 
Heavy industry is one of the largest industries producing various wastes. Zinc and lead ore deposits have been exploited for centuries in Olkusz, in the SE region of Poland. Mining and metallurgy plants in this region use the flotation process for ore enrichment. Zinc and lead ores occurring in dolomites contain approximately $5 \%$ of metals. Each year, 3 million tonnes of ores are processed, leaving circa 1.5 million tonnes of flotation wastes stored in sedimentation ponds as finegrained drift, which contains more than $3 \%$ of $\mathrm{Zn}, 1 \%$ of $\mathrm{Pb}$, and $0.01 \%$ of Cd, by weight. As reported by Ciarkowska et al. (2017), the amount of this waste accumulated in one of the industrial centres amounted to 50 million tonnes, excluding 110 ha of land for use. Our study was carried out on sediment from the processing of zinc and lead ores. Such processing consists of initial crushing and screening of ore and separating the concentrate by flotation in an aqueous environment. The process is often preceded by gravity enrichment in jig concentrators. Its final products are flotation concentrate and postflotation sediment. The latest is the remains of fragmented ore which is then transported to the pond in a hydrated form after flotation (Stefaniak et al. 2017). The unprotected surface of the post-flotation tailings pond poses a serious threat to the environment and human health due to its high susceptibility to blow-off and water erosion. It increases the risk of spreading contaminants such as heavy metals in the environment. The technology used in ore processing causes flotation waste to have a high percentage of very fine particles (usually around $85 \%$ ) and a minimal percentage of skeletal parts, which has a negative influence on their physical properties (MartinezPagan et al. 2011; Moreno-Barriga et al. 2017). Additionally, the disadvantageous growth conditions result from the alkaline $\mathrm{pH}$ (Kordas et al. 2018).

According to Krawczyńska et al. (2015) and Ciarkowska et al. (2017), the way to reduce the adverse impact of this waste from landfills on neighbouring areas is to cover them with vegetation. However, this is very problematic, because of the need to create appropriate conditions for plant growth and development, which are unfavourable due to the physical properties and chemistry of these wastes (Gul et al. 2015; Krawczyńska et al. 2015; Yuan et al. 2016; Ojuederie and Babalola 2017). Moreover, in the case of arable lands adjacent to the areas occupied for post-flotation tailings ponds, there is a real risk that heavy metals will accumulate in plant biomass. The use of such biomass for feed purposes can be a source of heavy metals in the food chain (Zahra et al. 2014; Yuan et al. 2018). The study of Krawczyńska et al. (2015) showed that the addition of pulp, waste from sugar production to PFS, increased the leaching of trace elements, especially copper. To increase the efficiency of phytostabilisation, these authors used biopreparations for seed treatment and biosurfactants supporting the accumulation of trace elements, especially in monocotyledonous plants. Our study focused on assessing the synergistic effect of organic and mineral mixtures with different sorption properties and different binding affinity for heavy metals. It was assumed that the introduction of such mixtures into PFS would not only reduce heavy metal mobility, but also enable the growth and development of plants as a result of improved physico-chemical properties.

A complete or at least partial reduction of the mobility of heavy metal ions in post-flotation sediment can be obtained by introducing into them various organic and mineral materials or mixtures thereof. As stated by Gul et al. (2015), combinations of organic and mineral materials introduced into post-flotation sediment have multidirectional abilities to immobilise heavy metals. Due to the nature and properties of mineral and organic materials, the immobilisation of heavy metals in a substrate enriched with these materials can be attributed to several chemical processes, including ion exchange, chemical sorption, and complexation (Gul et al. 2015; Li et al. 2017; Boros-Lajszner et al. 2018). As argued by Park et al. (2011) and Usman et al. (2013), the immobilisation of heavy metals can occur as a result of precipitation with minerals such as carbonates, silicates, and phosphates. These compounds come from materials introduced into the waste or result from processes caused by their application. The addition of organic or mineral materials to the substrate may also limit the mobility of heavy metals by changing the redox potential. It was reported by Choppala et al. (2012), who gave an example of the effect of biochar addition to soil on $\mathrm{Cr}^{+6}$ to $\mathrm{Cr}^{+3}$ transformations. The relative contribution of individual mechanisms to the immobilisation of heavy metals after the application of various materials is difficult to define clearly. Although, according to Houben et al. (2013), the change in soil or substrate $\mathrm{pH}$ is the decisive factor here. According to Krawczyńska et al. (2015), in the case of waste phytostabilisation, growing should be preceded by activities related to achieving the appropriate conditions necessary for the development of plants, including $\mathrm{pH}$ regulation, enrichment in organic matter, and supplementation of plant nutrients.

Due to unfavourable physical properties, high heavy metal content, as well as the lack of plant nutrients in PFS, which is the issue often raised in the literature, mineral-organic mixtures of soil and functionalised materials (biochar, zeolite) were prepared and additionally enriched with poultry litter or slurry. The addition of poultry litter or slurry was dictated by the desire to enrich the mixture with essential plant nutrients such as nitrogen, phosphorus, and potassium. Determining the response of microorganisms and plants to the introduction into the PFS of poultry litter or slurry is an important cognitive aspect in terms of challenges posed to modern science by the problems of biological reclamation of onerous landfills. Assuming that individual application of the materials used in the study will not meet the expectations, especially in the field of phytostabilisation of environmentally harmful post-flotation sediment landfills, it is fully justified to attempt to enrich them with other materials, and the synergistic effect of mixtures will enhance their beneficial impact on the environment. However, bearing in mind 
that this is an entirely innovative approach to the problem and a relatively short study period, no spectacular effects can be expected. The focus should be on refining the share of individual components in the mixture so that the biochemical processes in PFS do not adversely affect plant growth and development. The diverse mechanisms of heavy metal retention by biochar (surface functional groups), zeolite (channel and chamber system), and soil (sorption complex) make the combination of these materials a significantly effective system in stabilising heavy metals in PFS that has not been analysed yet. We hypothesise that enrichment of mixtures of soil and functionalised materials (biochar, zeolite) in poultry litter or slurry increases the biochemical activity of PFS, creates better conditions for plant growth and development as a result of increased availability of nutrients, and also reduces the mobility of heavy metals. The study aimed to determine the effect of mixtures differing in composition on (i) heavy metal mobility in PFS, (ii) heavy metal accumulation in willow, and (iii) PFS respiratory activity.

\section{Materials and methods}

\subsection{Properties of materials used in the experiment}

The substrate used in the experiment was post-flotation sediment obtained from a zinc and lead ore processing enterprise located in southern Poland. Other minerals (soil, zeolite) and organic materials (biochar, poultry litter, slurry) were used to prepare mixtures introduced into the post-flotation sediment. The soil was collected from a $0-0.2-\mathrm{m}$ layer of an arable field located several kilometres west of Cracow. The zeolite was produced from fly ash through hard coal combustion at the 'Kozienice' power plant (Franus et al. 2014). Biochar was produced from willow under limited access to air, at $350{ }^{\circ} \mathrm{C}$. Poultry litter and slurry came from farms located in southern Poland. The properties of materials used in the experiment are presented in Tables 1 and 2 .

\subsection{Physical and chemical analyses of the materials used in the experiment}

The granulometric composition of post-flotation sediment and soil was determined by the aerometric method. Measurement of the particle size of the zeolite material was carried out by the laser diffraction method on a Saturn DigiSizer II, Micromeritics apparatus. To identify the chemical properties of materials, they were ground to the size of $1 \mathrm{~mm}$ in a laboratory mill, dried at $105{ }^{\circ} \mathrm{C}$ for $12 \mathrm{~h}$ (Jindo et al. 2012), and then analysed. The $\mathrm{pH}$ values were determined potentiometrically $(\mathrm{CP}-505 \mathrm{pH}$ meter, ELMETRON, Zabrze, Poland), while the EC values conductometrically (CPC-502 conductometer, ELMETRON, Zabrze, Poland), maintaining the material: water ratio of $1: 2.5$ in the case of minerals, and 1:5 in the case of organic materials. Organic carbon in postflotation sediment and soil was determined by the titration oxidation method, while total carbon in organic materials was specified using the CNS analyser (Vario EL Cube, Elementar Analysensysteme GmbH, Hanau Germany). The total contents of $\mathrm{Zn}, \mathrm{Pb}, \mathrm{Cd}, \mathrm{Cu}$, and $\mathrm{Ni}$ were determined after ashing the sample in a chamber furnace at $450{ }^{\circ} \mathrm{C}$ for $12 \mathrm{~h}$ and mineralising its residues in a mixture of concentrated nitric and perchloric acids (3:2) (v/v). The content of the studied heavy metals was determined in the obtained solutions by inductively coupled plasma optical emission spectrometry (ICP-OES, PerkinElmer Optima 7300 DV, Waltham, MA, USA) (Oleszczuk et al. 2007). Table 3 presents detection limits for determining heavy metals.

The specific surface area and porosity were determined from $\mathrm{N}_{2}$ gas adsorption/desorption isotherms at $-196{ }^{\circ} \mathrm{C}$ using the ASAP 2020 apparatus (Micromeritics, Norcross, GA, USA). Prior to measurements, the samples were outgassed for $12 \mathrm{~h}$ at $105^{\circ} \mathrm{C}$. Based on the data obtained from $\mathrm{N}_{2}$ isotherms, specific surface area $\left(S_{\mathrm{BET}}\right)$ was calculated by applying Brunauer-Emmett-Teller (BET) equation (Brunauer et al. 1938). The total pore volume was calculated from the amount of $\mathrm{N}_{2}$ adsorbed at a relative vapour pressure $(P / \mathrm{P} 0) \sim$

Table 1 Selected physical and chemical properties of materials used in the experiment

\begin{tabular}{|c|c|c|c|c|c|c|}
\hline \multirow[t]{2}{*}{ Material } & \multicolumn{3}{|c|}{ Granulometric composition (\%) } & \multirow[t]{2}{*}{$\mathrm{pH} \mathrm{H}_{2} \mathrm{O}$} & \multirow{2}{*}{$\begin{array}{l}\mathrm{EC} \\
\mathrm{mS} \mathrm{cm}{ }^{-1}\end{array}$} & \multirow{2}{*}{$\begin{array}{l}\mathrm{C} \\
\mathrm{g} \mathrm{kg}^{-1} \mathrm{DM}\end{array}$} \\
\hline & $1-0.1 \mathrm{~mm}$ & $0.1-0.02 \mathrm{~mm}$ & $<0.02 \mathrm{~mm}$ & & & \\
\hline Post-flotation sediment (PFS) & 70 & 21 & 9 & $7.37 \pm 0.13$ & $0.76 \pm 0.02$ & $2.61 * \pm 0.01$ \\
\hline Soil $(\mathrm{S})$ & 17 & 31 & 52 & $5.08 \pm 0.04$ & $0.03 \pm 0.00$ & $26.6^{*} \pm 0.6$ \\
\hline Zeolite (Z) & 15 & 50 & 35 & $12.39 \pm 0.05$ & $2.28 \pm 0.11$ & $343.0 \pm 0.0$ \\
\hline Biochar (BC) & nd & nd & nd & $7.23 \pm 0.34$ & $2.26 \pm 0.65$ & $690.8 \pm 3.7$ \\
\hline Poultry litter (PL) & nd & nd & nd & $6.95 \pm 0.01$ & $1.87 \pm 0.07$ & $400.5 \pm 0.0$ \\
\hline Slurry (SL) & nd & nd & nd & $6.07 \pm 0.01$ & $1.88 \pm 0.05$ & $441.6 \pm 2.8$ \\
\hline
\end{tabular}

* Organic carbon, $n d$ not determined, \pm standard deviation 
Table 2 Total content of selected heavy metals in material used in the experiment

\begin{tabular}{llllll}
\hline Material & $\begin{array}{l}\mathrm{Zn} \\
\mathrm{mg} \mathrm{kg}\end{array}$ & $\mathrm{Pb}$ & $\mathrm{Cd}$ & $\mathrm{Cu}$ & $\mathrm{Ni}$ \\
\hline Post-flotation sediment (PFS) & $10.20 \pm 48$ & $7500 \pm 29$ & $69.6 \pm 1.9$ & $15.81 \pm 2.23$ & $14.15 \pm 1.14$ \\
Soil (S) & $117.4 \pm 0.4$ & $32.9 \pm 0.4$ & $0.68 \pm 0.04$ & $9.67 \pm 0.45$ & $23.65 \pm 0.16$ \\
Zeolite (Z) & $82.8 \pm 2.6$ & $24.8 \pm 0.3$ & $0.61 \pm 0.03$ & $61.04 \pm 0.75$ & $42.38 \pm 0.55$ \\
Biochar (BC) & $123.9 \pm 1.7$ & $4.52 \pm 0.21$ & $1.72 \pm 0.01$ & $10.14 \pm 0.51$ & $4.69 \pm 0.69$ \\
Poultry litter (PL) & $388.0 \pm 13.6$ & $2.24 \pm 0.20$ & $0.72 \pm 0.01$ & $68.30 \pm 1.43$ & $9.05 \pm 0.02$ \\
Slurry (SL) & $607.8 \pm 4.5$ & $1.61 \pm 0.03$ & $0.61 \pm 0.04$ & $78.95 \pm 10.11$ & $12.20 \pm 0.83$ \\
\hline
\end{tabular}

\pm Standard deviation

0.99. The volume of micropores was calculated by applying the Dubinin-Radushkevich method (Dubinin 1960). The mesopore volume was determined from the adsorption branch of the isotherms by the BJH (Barrett-Joyner-Halenda) method (Barrett et al. 1951) in the mesopore range proposed by Dubinin (Dubinin 1960). The macropore volume ( $\left.V_{\text {mac }}\right)$ was calculated using Eq. (1):

$V_{\mathrm{mac}}=V_{\mathrm{tot}}^{0.99}-\left(V_{\mathrm{mic}}^{\mathrm{DR}}+V_{\mathrm{mes}}^{\mathrm{BJH}}\right)$

$V_{\text {mic }}{ }^{\mathrm{DR}}$ the volume of micropores, and

$V_{\text {mes }}{ }^{\text {BJH }}$ the volume of mesopores.

Textural parameters of the organic materials are presented in Table 4.

\subsection{Pot experiment}

Growing tests were carried out under laboratory conditions in PVC containers containing $500 \mathrm{~g}$ of post-flotation sediment. The experimental scheme consisted of five treatments carried out in three replications: post-flotation sediment without additions (PFS) - control treatment; post-flotation sediment + (biochar + zeolite) mixture-PFS+ $(\mathrm{BC}+\mathrm{Z})$; post-flotation sediment + (biochar + zeolite + soil $)$ mixture-PFS $+(B C+$ $\mathrm{Z}+\mathrm{S})$; post-flotation sediment + (biochar + zeolite + soil + poultry litter $)-\mathrm{PFS}+(\mathrm{BC}+\mathrm{Z}+\mathrm{S}+\mathrm{PL})$, and post-flotation sediment + (biochar + zeolite + soil + slurry $)$ mixture$\mathrm{PFS}+(\mathrm{BC}+\mathrm{Z}+\mathrm{S}+\mathrm{SL})$.

Table 3 Detection limits for individual elements

\begin{tabular}{lll}
\hline Element & Wave length & Detection limit $\left(\mu \mathrm{g} \mathrm{l}^{-1}\right)$ \\
\hline $\mathrm{Cd}$ & 228.802 & 0.0027 \\
$\mathrm{Cu}$ & 327.393 & 0.0097 \\
$\mathrm{Ni}$ & 231.604 & 0.0150 \\
$\mathrm{~Pb}$ & 220.353 & 0.0420 \\
$\mathrm{Zn}$ & 206.200 & 0.0059 \\
\hline
\end{tabular}

The amount of each material (BC, Z, S, PL, SL) introduced into the PFS was $1 \%$ (w/w). After introducing mineral-organic mixtures into the post-flotation sediment, the material was moistened with distilled water and thoroughly mixed. Then, the material was placed in PVC containers. After $24 \mathrm{~h}$, a willow (clone 1052) was planted. During the plant's growth, the material moisture content was maintained at $60 \%$ of water capacity. The experiment was conducted for 90 days. After that time, the plant's aerial parts were collected. The collected biomass of the aerial parts was dried to a constant weight at $105^{\circ} \mathrm{C}$, and then, its amount was determined.

\subsection{Chemical analyses}

After the pot experiment, the post-flotation sediment with and without organic-mineral mixtures was dried at room temperature $\left(25^{\circ} \mathrm{C}\right)$. The following parameters were determined in the post-flotation sediment and post-flotation sediment with the addition of organic-mineral mixtures: $\mathrm{pH}-$ potentiometrically (CP-505 $\mathrm{pH}$ meter, ELMETRON, Zabrze, Poland) in a suspension of sediment and distilled water (sediment:water $=1: 2.5)$, electrical conductivity $(\mathrm{EC}-$ conductometrically (CPC-502 conductometer, ELMETRON, Zabrze, Poland) (sediment: water = 1:2.5). Heavy metals were extracted with water for $24 \mathrm{~h}$ (soil:solution $=1: 10$ ) as well as with $1 \mathrm{~mol} \mathrm{dm}^{-3}$ solution of $\mathrm{NH}_{4} \mathrm{NO}_{3}$ for $2 \mathrm{~h}$ (Park et al. 2011). The heavy metal content was determined in the obtained extracts by inductively coupled plasma optical emission spectrometry (ICP-OES, PerkinElmer Optima 7300 DV, Waltham, MA, USA) (Oleszczuk et al. 2007).

\subsection{Respiratory activity}

Respiratory activity of post-flotation sediment with and without organic-mineral materials was determined by the manometric method, using the Oxi-Top (Wissenschaftlich Technische Werkstatten GmbH, Weliheim, Germany) measuring apparatus, in accordance with ISO 14855-1:2005 (Picture 1). The test was carried out on the same material 
Table 4 The textural parameters of the organic materials

\begin{tabular}{llllll}
\hline Material & $\begin{array}{l}\text { BET surface } \\
\text { area }\left(\mathrm{m}^{2} \mathrm{~g}^{-1}\right)\end{array}$ & $\begin{array}{l}\text { Total pore volume } \\
\left(\mathrm{cm}^{3} \mathrm{~g}^{-1}\right)\end{array}$ & $\begin{array}{l}\text { Volume of micropores } \\
\left(\mathrm{cm}^{3} \mathrm{~g}^{-1}\right)\end{array}$ & $\begin{array}{l}\text { Volume of micropores } \\
\left(\mathrm{cm}^{3} \mathrm{~g}^{-1}\right)\end{array}$ & $\begin{array}{l}\text { Volume of } \\
\left.\mathrm{macropores}^{(} \mathrm{cm}^{3} \mathrm{~g}^{-1}\right)\end{array}$ \\
\hline Biochar (BC) & 1.36 & 0.003 & $<0.001$ & 0.001 & 0.002 \\
Slurry (SL) & 0.87 & 0.003 & $<0.001$ & 0.001 & 0.002 \\
Poultry litter (PL) & 0.89 & 0.005 & $<0.001$ & 0.002 & 0.003 \\
\hline
\end{tabular}

prepared for the pot experiment. The weight of the sample used to determine the respiratory activity corresponded to $25 \mathrm{~g}$ dry weight. The test was carried out in two replicates.

The manometric measurement of respiratory activity of the studied materials involved the recording of pressure changes in closed containers in a continuous system (Picture 1). Pressure changes are proportional to the amount of oxygen consumed by the sample as a result of respiratory processes occurring in it (OxiTop® 2003). Measuring time for respiratory activity was 90 days (including the lag-faze period to stabilise conditions and period of actual measurements of respiratory activity). Pressure changes were automatically recorded every $60 \mathrm{~min}$. The resulting equivalent quantities of $\mathrm{CO}_{2}$ were absorbed by $1 \mathrm{~mol} \mathrm{dm}^{-3} \mathrm{NaOH}$ present in the vessels. The system used for the measurement of respiratory activity consisted of $1.0 \mathrm{dm}^{3}$-measuring glass vessels with accessories. For the time of determination, measuring vessels were put into a thermostatic cabinet, providing a constant temperature of $25.0{ }^{\circ} \mathrm{C}\left( \pm 0.1{ }^{\circ} \mathrm{C}\right)$. Measurement data was sent to the controller through an infrared interface, and then, to the computer using Achat OC. Respiratory activity of materials was converted into dry matter by the following formula:

$\mathrm{BA}=\frac{M O_{2}}{R \cdot T} \cdot \frac{V_{\mathrm{fr}}}{m_{\mathrm{Bt}}} \cdot|\Delta p|\left[\mathrm{mgO}_{2}(\mathrm{~g} \cdot \mathrm{d})^{-1}\right]$

where BA is biological activity; $\mathrm{MO}_{2}$ is the molecular weight of oxygen $\left(31,998 \mathrm{mg} \mathrm{mol}^{-1}\right) ; R$ is universal gas constant $\left(83.14 \mathrm{~L} \mathrm{hPa}\left(\mathrm{K} \mathrm{mol}^{-1}\right)^{-1} ; T\right.$ is measurement temperature $(\mathrm{K}) ; \mathrm{m}_{\mathrm{Bt}}$ is dry mass weight in the composted material $(\mathrm{kg}) ;|\Delta p|$ is pressure change $(\mathrm{hPa}) ; V_{\mathrm{fr}}$ is free gas volume.

\subsection{Analysis of plant material}

Samples of plant material aerial parts were mineralised in a chamber furnace at $450{ }^{\circ} \mathrm{C}$. The residue was dissolved in diluted nitric acid (1:2), and the content of the studied heavy metals was determined in the obtained solutions by inductively coupled plasma optical emission spectrometry (ICP-OES,
Picture. 1 OxiTop ${ }^{\circledR}$ Control measuring set for respiratory activity

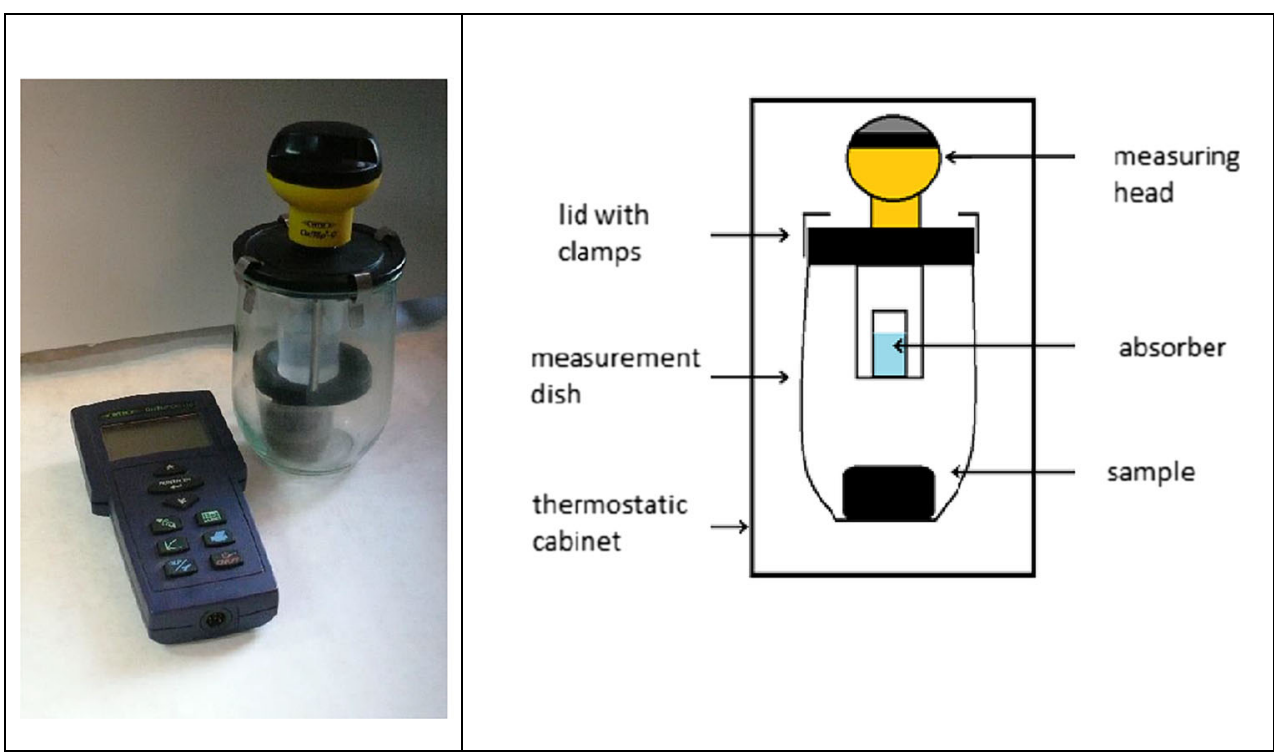

Pic. 1. OxiTop ${ }^{\circledR}$ Control measuring set for respiratory activity 
PerkinElmer Optima 7300 DV, Waltham, MA, USA) (Oleszczuk et al. 2007).

\subsection{Statistical analysis}

The experiment was performed in three replicates. The obtained data were compiled with the use of STATISTICA 12.5 (StatSoft Inc.). The mean values of analysed properties were compared using Tukey's multiple comparison test at $p \leq 0.05$. The value of the Spearman's rank correlation coefficient was calculated for selected parameters. Variations in the treatments were determined by calculating the standard deviation $( \pm \mathrm{SD})$.

\section{Results and discussion}

\subsection{The properties of materials used in the study}

Due to their origin, the materials used in the study differed significantly in terms of physical properties and chemical composition (Tables 1, 2, and 4). The type of materials added to post-flotation sediment (PFS) facilitated their division into two groups: mineral materials (zeolite, soil) and organic materials (biochar, poultry litter, slurry). The additions of mineral materials $(\mathrm{Z}, \mathrm{S})$ had different granulometric composition, $\mathrm{pH}$, and EC values, as well as the $\mathrm{C}$ content (Table 2). Organic additions (BC, PL, SL) had similar values of the analysed parameters. Irrespective of the material used, the content of tested heavy metals, apart from copper and nickel, was lower than in post-flotation sediment. Significant discrepancies in $S_{\mathrm{BET}}$ between biochar and other organic materials were noted (Table 4).

\section{$3.2 \mathrm{pH}$ and electrical conductivity (EC) in post- flotation sediment after the experiment}

The $\mathrm{pH}$ values measured in the suspension of post-flotation sediment and water varied depending on the composition of the mixtures introduced. The addition of $\mathrm{Z}$ and $\mathrm{BC}$ to postflotation sediment (PFS) significantly increased the $\mathrm{pH}$ value of the substrate compared to the control (Fig. 1). After adding $\mathrm{BC}+\mathrm{Z}+\mathrm{S}+\mathrm{PL}$ and $\mathrm{BC}+\mathrm{Z}+\mathrm{S}+\mathrm{SL}$ mixtures, the substrate $\mathrm{pH}$ value changed significantly. The lowest $\mathrm{pH}$ was determined for $\mathrm{PFS}+(\mathrm{BC}+\mathrm{Z}+\mathrm{S}+\mathrm{SL})$ treatment. Differences in $\mathrm{pH}$ values in treatments with organic-mineral mixtures resulted from the properties of the materials used. Both biochar and zeolite have a deacidifying effect (Gondek and MierzwaHersztek 2016; Mierzwa-Hersztek et al. 2019; Lahori et al. 2020). The introduction of mixtures with the addition of poultry litter or slurry into PFS significantly reduced the substrate's $\mathrm{pH}$. This might be attributed to the release of the hydrogen load combined with organic anions derived from the mineralisation of organic materials (poultry litter, slurry). The nitrification process may be another reason for the apparent increase in PFS acidification after applying mixtures enriched with poultry litter or slurry (Porter et al., 1980). Lower pH value of post-flotation sediment after introducing the mixtures may result in increased release and transformation of heavy metal fractions (Krawczyńska et al. 2015). On the other hand, maintaining a high $\mathrm{pH}$, while carrying out reclamation activities that require the supplementation of nutrients (e.g. phosphorus), may limit their availability. Zaidun et al. (2019) demonstrated that the combined use of $10 \mathrm{t} \mathrm{ha}^{-1}$ of biochar and $2.5 \mathrm{t} \mathrm{ha}^{-1}$ of zeolite increased the soil $\mathrm{pH}$ by $7 \%$.

The electrical conductivity (EC) value (Fig. 2) measured for post-flotation sediment was nearly $0.8 \mathrm{mS} \mathrm{cm}^{-1}$. The electrical conductivity values of PFS significantly decreased for all mixtures introduced. The lowest EC values (by nearly 50\% compared to PFS) were noted for treatments modified with poultry litter or slurry mixtures. The study revealed that the introduction of the carbon and zeolite mixture into PFS significantly reduced EC. It indicates that the prepared mixtures have the potential to reduce the active ion content in the solution, which is responsible for its salinity. It may be justified by both chemical and physical properties of biochar and zeolite, which, due to their production method, have a structure effective in immobilising various substances, including ions.

\subsection{The content of mobile $\mathrm{Cu}, \mathrm{Cd}, \mathrm{Pb}$, and $\mathrm{Zn}$ in post- flotation sediment enriched with various mixtures}

The effect of the materials used on heavy metal $(\mathrm{Cu}, \mathrm{Cd}, \mathrm{Pb}$, $\mathrm{Zn}$, and $\mathrm{Ni}$ ) immobilisation was examined after extracting their most mobile forms with redistilled water or $1 \mathrm{~mol} \mathrm{dm}^{-3}$ solution of $\mathrm{NH}_{4} \mathrm{NO}_{3}$, which are often referred to as 'bioavailable'(Tessier et al. 1979; Zeien and Brümmer, 1989; Okoro et al. 2012). As is known, the share of these forms of heavy metals in the total content is minimal and usually below $5 \%$.

Significantly, the lowest content of water-dissolved zinc fraction $\mathrm{Zn}-\mathrm{H}_{2} \mathrm{O}$ was determined in post-flotation sediment modified with $\mathrm{BC}+\mathrm{Z}$ and $\mathrm{BC}+\mathrm{Z}+\mathrm{S}$ mixtures (Table 5). The introduction of mixtures with poultry litter PL and slurry SL into PFS significantly increased the $\mathrm{Zn}-\mathrm{H}_{2} \mathrm{O}$ content not only compared to the content determined in treatments modified with mixtures $(B C+Z)$ and $(B C+Z+S)$, but also to non-enriched post-flotation sediment (PFS). Following the extraction of $\mathrm{Zn}$ with $1 \mathrm{~mol} \mathrm{dm}{ }^{-3}$ solution of $\mathrm{NH}_{4} \mathrm{NO}_{3}$, significantly lower mobile zinc content was found in all treatments compared to PFS, regardless of the material added (Table 6). The tendency of higher $\mathrm{Zn}-\mathrm{NH}_{4} \mathrm{NO}_{3}$ content was not confirmed in treatments where $\mathrm{BC}+\mathrm{Z}+\mathrm{S}+\mathrm{PL}$ and $\mathrm{BC}+$ $\mathrm{Z}+\mathrm{S}+\mathrm{SL}$ mixtures were introduced into PFS.

The content of water-extracted lead $\left(\mathrm{Pb}-\mathrm{H}_{2} \mathrm{O}\right)$ in treatments where $\mathrm{BC}+\mathrm{Z}$ and $\mathrm{BC}+\mathrm{Z}+\mathrm{S}$ mixtures were applied did not 


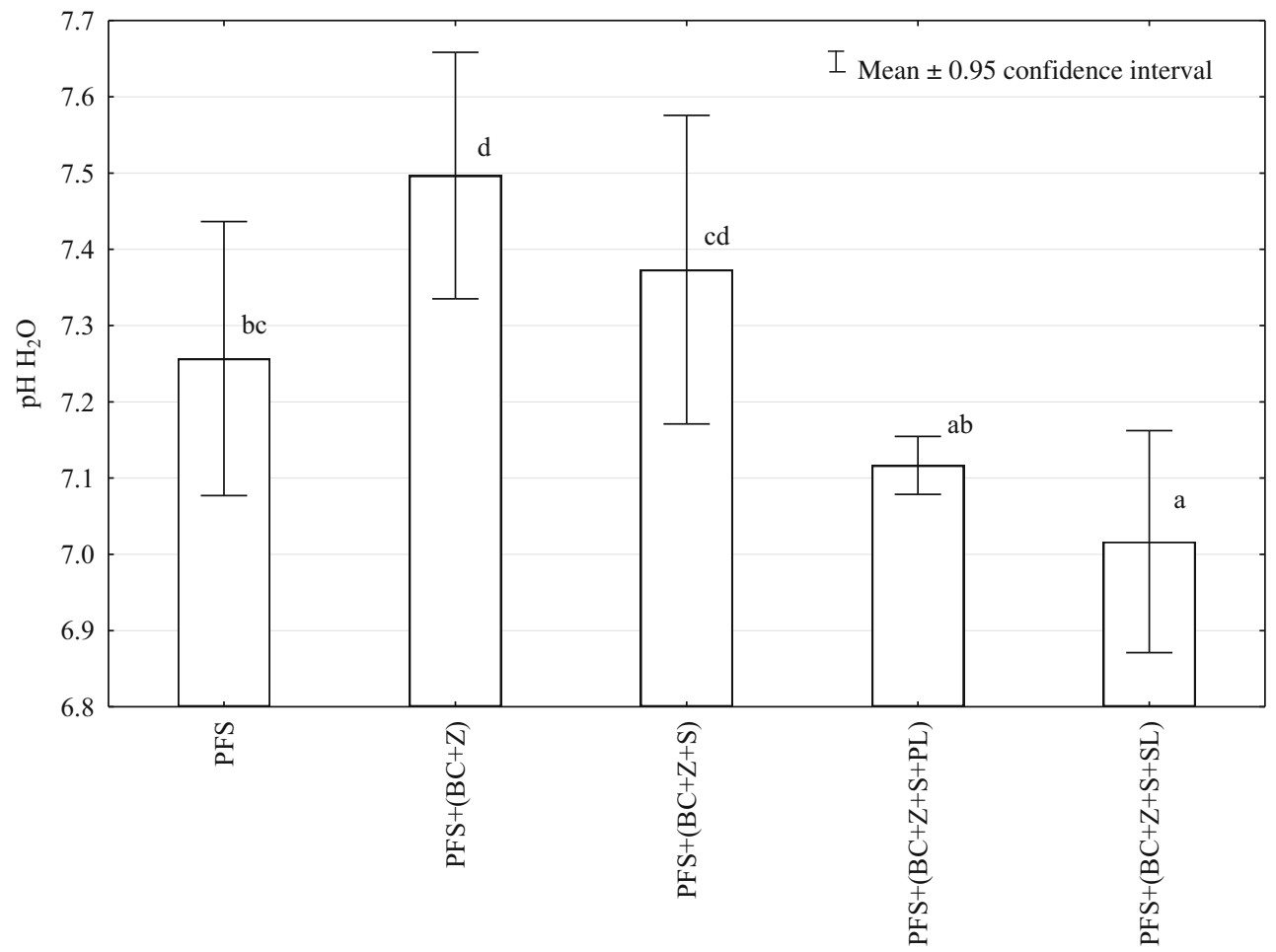

Fig. 1 The $\mathrm{pH}$ values measured in the substrate after the experiment. The mean values marked with the same letters do not differ statistically significantly at $p \leq 0.05$ (according to the Tukey's test). PFS, control treatment; PFS $+(\mathrm{BC}+\mathrm{Z})$, post-flotation sediment + (biochar + zeolite)

mixture; $\mathrm{PFS}+(\mathrm{BC}+\mathrm{Z}+\mathrm{S})$, post-flotation sediment + (biochar + zeolite + soil) mixture; $\mathrm{PFS}+(\mathrm{BC}+\mathrm{Z}+\mathrm{S}+\mathrm{PL})$, post-flotation sediment + (biochar + zeolite + soil + poultry litter) mixture; $\mathrm{PFS}+(\mathrm{BC}+\mathrm{Z}+\mathrm{S}+\mathrm{SL})$, postflotation sediment + (biochar + zeolite + soil + slurry) mixture

Fig. 2 The EC values measured in the substrate after the experiment. The mean values marked with the same letters do not differ statistically significantly at $p \leq 0.05$ (according to the Tukey's test). PFS, control treatment; $\mathrm{PFS}+(\mathrm{BC}+\mathrm{Z})$, postflotation sediment + (biochar + zeolite) mixture; $\mathrm{PFS}+(\mathrm{BC}+\mathrm{Z}+$ $S)$, post-flotation sediment + (biochar + zeolite + soil) mixture; $\mathrm{PFS}+(\mathrm{BC}+\mathrm{Z}+\mathrm{S}+\mathrm{PL})$, postflotation sediment + (biochar + zeolite + soil + poultry litter) mixture; $\mathrm{PFS}+(\mathrm{BC}+\mathrm{Z}+\mathrm{S}+\mathrm{SL})$, post-flotation sediment + (biochar + zeolite + soil + slurry) mixture

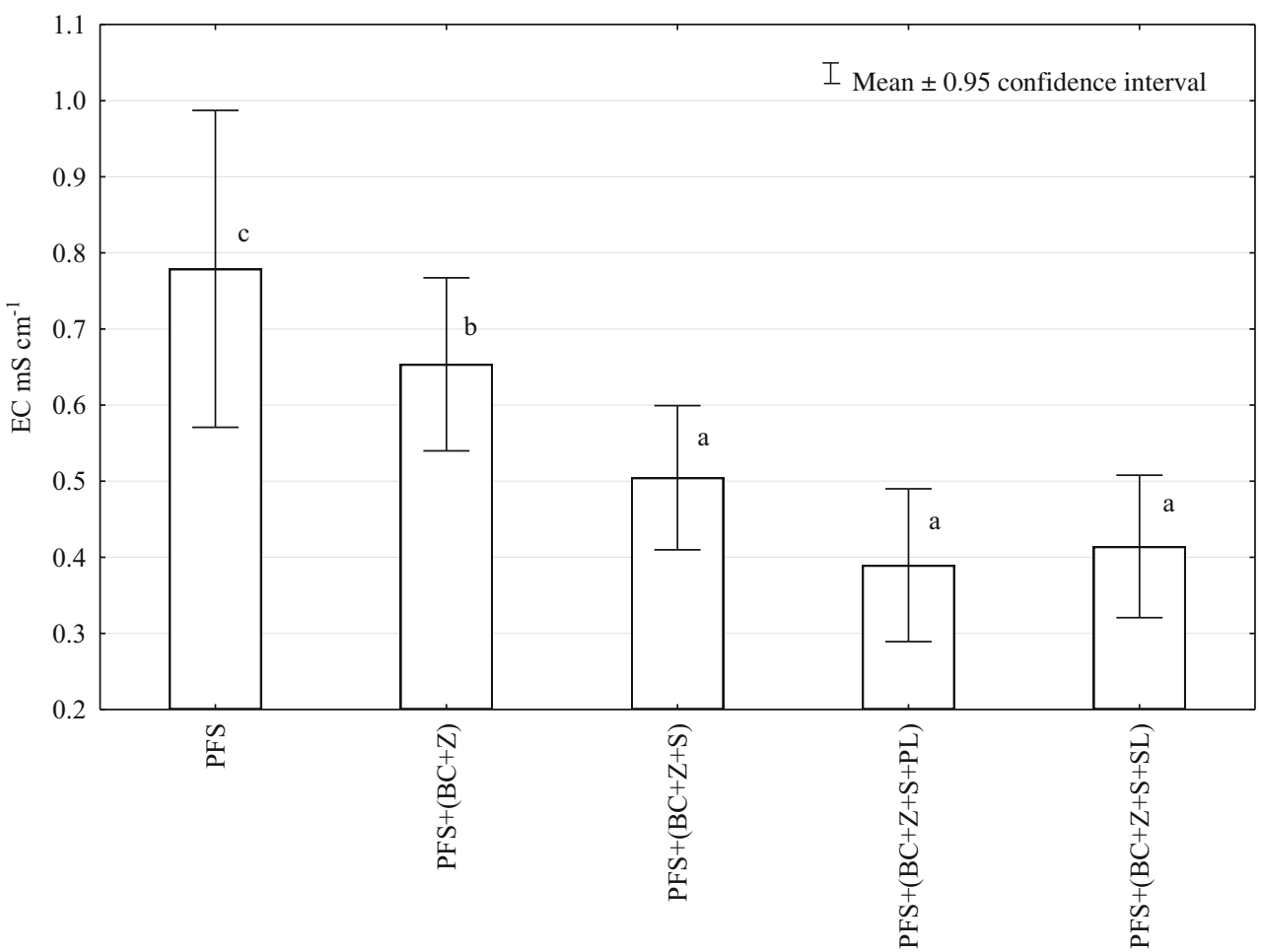


Table 5 The content of heavy metals in the $\mathrm{H}_{2} \mathrm{O}$ extract

\begin{tabular}{llllll}
\hline Treatment & $\begin{array}{l}\mathrm{Zn}-\mathrm{H}_{2} \mathrm{O} \\
\mathrm{mg} \mathrm{kg}{ }^{-1} \mathrm{DM}\end{array}$ & $\mathrm{Pb}-\mathrm{H}_{2} \mathrm{O}$ & $\mathrm{Cd}-\mathrm{H}_{2} \mathrm{O}$ & $\mathrm{Cu}-\mathrm{H}_{2} \mathrm{O}$ & $\mathrm{Ni}-\mathrm{H}_{2} \mathrm{O}$ \\
\hline $\mathrm{PFS}$ & $2.46 \mathrm{~b} \pm 0.41$ & $0.08 \mathrm{a} \pm 0.01$ & $0.087 \mathrm{~b} \pm 0.012$ & $<\mathrm{LD}$ & $0.038 \mathrm{a} \pm 0.004$ \\
$\mathrm{PFS}+(\mathrm{BC}+\mathrm{Z})$ & $0.88 \mathrm{a} \pm 0.05$ & $0.06 \mathrm{a} \pm 0.01$ & $0.047 \mathrm{a} \pm 0.011$ & $<\mathrm{LD}$ & $0.026 \mathrm{a} \pm 0.010$ \\
$\mathrm{PFS}+(\mathrm{BC}+\mathrm{Z}+\mathrm{S})$ & $0.80 \mathrm{a} \pm 0.07$ & $0.10 \mathrm{a} \pm 0.02$ & $0.043 \mathrm{a} \pm 0.015$ & $<\mathrm{LD}$ & $0.027 \mathrm{a} \pm 0.006$ \\
$\mathrm{PFS}+(\mathrm{BC}+\mathrm{Z}+\mathrm{S}+\mathrm{PL})$ & $5.76 \mathrm{~d} \pm 0.15$ & $5.47 \mathrm{c} \pm 0.10$ & $0.050 \mathrm{a} \pm 0.010$ & $0.130 \mathrm{~b} \pm 0.027$ & $0.147 \mathrm{c} \pm 0.012$ \\
$\mathrm{PFS}+(\mathrm{BC}+\mathrm{Z}+\mathrm{S}+\mathrm{SL})$ & $4.46 \mathrm{c} \pm 0.31$ & $3.24 \mathrm{~b} \pm 0.09$ & $0.040 \mathrm{a} \pm 0.000$ & $0.013 \mathrm{a} \pm 0.006$ & $0.118 \mathrm{~b} \pm 0.011$ \\
\hline
\end{tabular}

$<L D$ values below the detection limit

The mean values marked with the same letters do not differ statistically significantly at $\alpha \leq 0.05$ (according to the Tukey's test)

$P F S$, control treatment; $P F S+(B C+Z)$, post-flotation sediment + (biochar + zeolite) mixture; $P F S+(B C+Z+S)$, post-flotation sediment $+($ biochar + zeolite + soil) mixture; $P F S+(B C+Z+S+P L)$, post-flotation sediment + (biochar + zeolite + soil + poultry litter) mixture; $P F S+(B C+Z+S+S L)$, post-flotation sediment + (biochar + zeolite + soil + slurry) mixture

exceed $0.10 \mathrm{mg} \mathrm{kg}^{-1} \mathrm{DM}$ of the substrate. The enrichment of the mixture containing biochar, zeolite, and soil with poultry litter or slurry significantly increased the $\mathrm{Pb}-\mathrm{H}_{2} \mathrm{O}$ content (Table 3). A similar relation was obtained after extraction of $\mathrm{Pb}$ with $\mathrm{NH}_{4} \mathrm{NO}_{3}$ solution (Table 5).

The cadmium content in $\mathrm{H}_{2} \mathrm{O}$-extracted post-flotation sediment was at a similar level $\left(0.040-0.050 \mathrm{mg} \mathrm{kg}^{-1} \mathrm{DM}\right.$ of the substrate) regardless of the mixture used (Table 4 ). The addition of organic-mineral mixtures contributed to over $40 \%$ reduction of $\mathrm{Cd}-\mathrm{H}_{2} \mathrm{O}$ in post-flotation sediment (Table 5). The content of $\mathrm{Cd}$ extracted with $\mathrm{NH}_{4} \mathrm{NO}_{3}$ solution indicated that there was a significant decrease in the mobile element after applying $\mathrm{BC}+\mathrm{Z}+\mathrm{S}+\mathrm{PL}$ and $\mathrm{BC}+$ $\mathrm{Z}+\mathrm{S}+\mathrm{SL}$ mixtures. The reduction of $\mathrm{Cd}-\mathrm{NH}_{4} \mathrm{NO}_{3}$ forms in these treatments was over $90 \%$ on average compared to the control treatment (PFS).

The water-extracted $\mathrm{Cu}$ forms were determined neither in PFS nor in $\mathrm{PFS}+(\mathrm{BC}+\mathrm{Z})$ and $\mathrm{PFS}+\mathrm{BC}+\mathrm{Z}+\mathrm{S})$ treatments (Table 5). In treatments where the $\mathrm{BC}+\mathrm{Z}+\mathrm{S}$ mixture was modified with poultry litter (PL) or slurry (SL), $0.130 \mathrm{mg} \mathrm{Cu} \mathrm{kg}^{-1}$ $\mathrm{DM}$ of the substrate and $0.013 \mathrm{mg} \mathrm{Cu} \mathrm{kg}{ }^{-1} \mathrm{DM}$ of the substrate, were noted respectively. Contents of mobile $\mathrm{Cu}$ extracted with $\mathrm{NH}_{4} \mathrm{NO}_{3}$ solution showed an inverse relationship, as they were almost $90 \%$ higher in the PFS, PFS+(BC $+\mathrm{Z})$, and PFS+(BC+ $\mathrm{Z}+\mathrm{S})$ treatments.

The content of nickel extracted with both water and $\mathrm{NH}_{4} \mathrm{NO}_{3}$ was significantly the highest in treatments where $\mathrm{BC}+\mathrm{Z}+\mathrm{S}+$ $\mathrm{PL}$ and $\mathrm{BC}+\mathrm{Z}+\mathrm{S}+\mathrm{SL}$ mixtures were applied (Tables 5 and 6 ). In the case of mobile nickel, a significant reduction was noted only after extraction with $\mathrm{NH}_{4} \mathrm{NO}_{3}$ and introduction of $\mathrm{BC}+\mathrm{Z}$ and $\mathrm{BC}+\mathrm{Z}+\mathrm{S}$ mixtures into PFS. The study showed a diverse impact of mixtures applied on the content of tested mobile heavy metals in post-flotation sediment. It was not only the result of the element type but also the composition of the mixture used. The calculated values of Spearman correlation coefficients indicate that the content of mobile elements was highly influenced by $\mathrm{pH}$ and EC (Table 7).
In their study, Krawczyńska et al. (2015) attempted to determine the effect of organic materials on heavy metal availability in post-flotation sediment. As demonstrated by these authors, the introduction into post-flotation sediments of pulp produced in the sugar beet treating process increased copper leaching, as well as the toxicity of extracts. On the other hand, Ciarkowska et al. (2017) reported a positive effect of the addition of sewage sludge to post-flotation sediment, that is, among others, a reduction in the available zinc content. However, it should be noted that organic materials are mineralised after their introduction into post-flotation sediment. In turn, this results in the degradation of organic connections containing heavy metals. Our results confirm this. The process of releasing heavy metals may, especially at lower $\mathrm{pH}$ values, increase at a rate. Taking into account the lower durability of organic connections to the microbiological factor, compared to hardly degraded connections in postflotation sediment, the desire to limit the heavy metal mobility after using biologically unstable organic materials can have the opposite effect. According to the study of Mierzwa-Hersztek et al. (2019), in a soil artificially contaminated with $\mathrm{Zn}, \mathrm{Pb}$, and $\mathrm{Cd}$, the reduced mobility of heavy metal ions may be associated with a change of substrate properties, including redox potential, $\mathrm{pH}$ value, as well as the introduction into the soil of materials with significantly developed sorption surfaces able to effectively bind metal ions. These authors argued that the adsorbents used (zeolite, biochar) have the potential to sorb heavy metals from contaminated soils. Also, the degree of their immobilisation depends on the metal type, its concentration in the solution, as well as the dose and adsorbent used. It should also be noted that time can be an important factor modifying the efficiency of heavy metal immobilisation when using these materials.

\subsection{Respiration activity}

For the study period (90 days), curves were drawn corresponding to oxygen demand. Then, these curves were divided 
Table 6 The content of heavy metals in the $1 \mathrm{~mol} \mathrm{dm}^{-3} \mathrm{NH}_{4} \mathrm{NO}_{3}$ extract

\begin{tabular}{lccccc}
\hline Treatment & $\mathrm{Zn}^{-\mathrm{NH}_{4} \mathrm{NO}_{3}}$ & $\mathrm{~Pb}-\mathrm{NH}_{4} \mathrm{NO}_{3}$ & $\begin{array}{l}\mathrm{Cd}-\mathrm{NH}_{4} \mathrm{NO}_{3} \\
\mathrm{mg} \mathrm{kg}\end{array}$ & $\mathrm{Cu}-\mathrm{NH}_{4} \mathrm{NO}_{3}$ & $\mathrm{Ni}-\mathrm{NH}_{4} \mathrm{NO}_{3}$ \\
\hline $\mathrm{PFS}$ & $19.2 \mathrm{c} \pm 0.7$ & $1.06 \mathrm{a} \pm 0.36$ & $0.61 \mathrm{~b} \pm 0.03$ & $0.59 \mathrm{~b} \pm 0.11$ & $0.17 \mathrm{~b} \pm 0.01$ \\
$\mathrm{PFS}+(\mathrm{BC}+\mathrm{Z})$ & $14.9 \mathrm{~b} \pm 2.4$ & $1.25 \mathrm{a} \pm 0.24$ & $0.65 \mathrm{bc} \pm 0.06$ & $0.42 \mathrm{~b} \pm 0.16$ & $0.09 \mathrm{a} \pm 0.01$ \\
$\mathrm{PFS}+(\mathrm{BC}+\mathrm{Z}+\mathrm{S})$ & $13.2 \mathrm{ab} \pm 1.2$ & $1.64 \mathrm{a} \pm 0.79$ & $0.76 \mathrm{c} \pm 0.08$ & $0.37 \mathrm{~b} \pm 0.03$ & $0.09 \mathrm{a} \pm 0.01$ \\
$\mathrm{PFS}+(\mathrm{BC}+\mathrm{Z}+\mathrm{S}+\mathrm{PL})$ & $11.2 \mathrm{a} \pm 0.7$ & $2.24 \mathrm{a} \pm 0.17$ & $0.05 \mathrm{a} \pm 0.00$ & $0.06 \mathrm{a} \pm 0.00$ & $0.22 \mathrm{c} \pm 0.01$ \\
PFS+(BC+Z+S + SL) & $12.2 \mathrm{ab} \pm 0.8$ & $2.07 \mathrm{a} \pm 0.56$ & $0.06 \mathrm{a} \pm 0.00$ & $0.04 \mathrm{a} \pm 0.00$ & $0.25 \mathrm{~d} \pm 0.02$
\end{tabular}

\pm , standard deviation; the mean values marked with the same letters do not differ statistically significantly at $\alpha \leq$ 0.05 (according to the Tukey's test)

$P F S$, control treatment; $P F S+(B C+Z)$, post-flotation sediment + (biochar + zeolite) mixture; $P F S+(B C+Z+S)$, post-flotation sediment $+($ biochar + zeolite + soil) mixture; $P F S+(B C+Z+S+P L)$, post-flotation sediment + (biochar + zeolite + soil + poultry litter) mixture; $P F S+(B C+Z+S+S L)$, post-flotation sediment + (biochar + zeolite + soil + slurry) mixture into two data strings up to 15 days and over 15 days. The directional coefficients of the trend line equations allowed the determination of differences in respiratory activity between treatments (Table 8).

The first 2 weeks of PFS mixtures incubation were characterised by poor respiratory response, except for treatments modified with poultry litter (PL) or slurry (SL). Oxygen consumption in these treatments was more than 50 times higher compared to the control treatment and more than 10 times compared to PFS with the addition of $B C+Z$ and $\mathrm{BC}+\mathrm{Z}+\mathrm{S}$ mixtures. The dynamic changes and differences were reduced after 2 weeks of incubation. After 2 weeks of measurement, the respiratory activity of materials was stable, as evidenced by determination coefficient values close to 1 . The $\mathrm{BC}, \mathrm{Z}$, and $\mathrm{S}$ additions differentiated respiratory activity by several per cent during this period. It can be regarded as the error limit of the method and biochemical determinations. The addition of PL or SL resulted in a higher demand for oxygen, and was at least twice as high as in other treatments. After 2 weeks of the experiment, constant equations also indicated significant dynamics of material respiratory processes in the initial incubation period. Higher respiratory activity in PFS+ $(\mathrm{BC}+\mathrm{Z}+\mathrm{S}+\mathrm{PL})$ and $\mathrm{PFS}+(\mathrm{BC}+\mathrm{Z}+\mathrm{S}+\mathrm{SL})$ treatments was mainly due to the introduction of nutrients (e.g. carbon, nitrogen) into the substrate, which are used in biochemical processes related to the functioning of microbial populations. Another reason for the increased respiratory activity confirmed by the study is the change in the substrate physical conditions, namely better aeration resulting from the improvement of its structure (Brauer and Aiken, 2006; Jiang et al. 2011).

\subsection{The amount of willow aerial parts and the heavy metal content in biomass}

The amounts of willow aerial parts were different in all treatments (Fig. 3). Significantly, the smallest amounts of biomass were collected in treatments where mixtures introduced into PFS contained poultry litter (PL) or slurry (SL). The results indicate significantly greater activity of microbiological processes in treatments where mixtures with poultry litter or slurry were applied. The increased biological activity was associated with a greater oxygen demand, which, according to our results, could have resulted in its reduction in the case of willow growth. Contents of the studied heavy metals in willow aerial parts varied not only by the element type, but also the composition of mixture added to PFS.

Compared to other treatments, the lowest amount of zinc in willow aerial parts was determined after applying $\mathrm{Z}+\mathrm{S}+\mathrm{PL}$ and $\mathrm{BC}+\mathrm{Z}+\mathrm{S}+\mathrm{SL}$ mixtures. When compared to the control treatment (PFS), the reduction of $\mathrm{Zn}$ content in the biomass of willow aerial parts was $22.3 \%$ for $\mathrm{PFS}+(\mathrm{BC}+\mathrm{Z}+\mathrm{S}+\mathrm{PL})$ and nearly $60 \%$ for PFS+ $(B C+Z+S+S L)$. Except for the PFS+ $(\mathrm{BC}+\mathrm{Z}+\mathrm{S}+\mathrm{SL})$ treatment, the lead content in willow aerial parts was higher than that determined in the control (Table 9). Significantly, the greatest amount of $\mathrm{Pb}$ was determined in

Table 7 Correlation Spearman analysis for heavy metals content and selected properties of post-flotation sediments

\begin{tabular}{|c|c|c|c|c|c|c|c|c|c|c|}
\hline Parameter & $\mathrm{Zn}-\mathrm{H}_{2} \mathrm{O}$ & $\mathrm{Pb}-\mathrm{H}_{2} \mathrm{O}$ & $\mathrm{Cd}-\mathrm{H}_{2} \mathrm{O}$ & $\mathrm{Cu}-\mathrm{H}_{2} \mathrm{O}$ & $\mathrm{Ni}-\mathrm{H}_{2} \mathrm{O}$ & $\mathrm{Zn}-\mathrm{NH}_{4} \mathrm{NO}_{3}$ & $\mathrm{~Pb}-\mathrm{NH}_{4} \mathrm{NO}_{3}$ & $\mathrm{Cd}-\mathrm{NH}_{4} \mathrm{NO}_{3}$ & $\mathrm{Cu}-\mathrm{NH}_{4} \mathrm{NO}_{3}$ & $\mathrm{Ni}-\mathrm{NH}_{4} \mathrm{NO}_{3}$ \\
\hline $\mathrm{pH} \mathrm{H} \mathrm{H}_{2} \mathrm{O}$ & $-0.81 * * *$ & $-0.77 * * *$ & -0.01 & $-0.77 * * *$ & $-0.80 * * *$ & 0.39 & $-0.52^{*}$ & $0.78 * * *$ & $0.68 * *$ & $-0.93 * * *$ \\
\hline $\mathrm{EC}$ & $-0.58^{*}$ & $-0.80 * * *$ & 0.46 & $-0.84 * * *$ & $-0.62 *$ & $0.82 * * *$ & $-0.72 * *$ & $0.57^{*}$ & $0.83 * * *$ & $-060^{*}$ \\
\hline
\end{tabular}

Significant at $* * * p \leq 0.001, * * p \leq 0.01, * p \leq 0.05$ 
Table 8 The trend line equations of respiratory activity in two periods

\begin{tabular}{|c|c|c|c|c|}
\hline \multirow[t]{2}{*}{ Treatment } & \multicolumn{2}{|l|}{ To the 15th day of incubation } & \multicolumn{2}{|c|}{ To the 15 th day of incubation } \\
\hline & $y=\left[\mathrm{mg} \mathrm{O}_{2}\left(\mathrm{~g} \mathrm{~d}^{-1}\right]\right.$ for $x=24 \mathrm{~h}$ & $R^{*}$ & $\begin{array}{l}y=\left[\mathrm{mg} \mathrm{O}_{2}\left(\mathrm{~g} \mathrm{~d}^{-1}\right]\right. \\
\text { for } x=24 \mathrm{~h}\end{array}$ & $R^{*}$ \\
\hline PFS & $y=0.0035 x+0.026$ & 0.5267 & $y=0.0139 x-0.11$ & 0.9785 \\
\hline $\mathrm{PFS}+(\mathrm{BC}+\mathrm{Z})$ & $y=0.0035 x+0.079$ & 0.7102 & $y=0.0139 x-0.073$ & 0.9632 \\
\hline $\mathrm{PFS}+(\mathrm{BC}+\mathrm{Z}+\mathrm{S})$ & $y=0.0139 x-0.032$ & 0.8635 & $y=0.0035 x+0.140$ & 0.9764 \\
\hline $\mathrm{PFS}+(\mathrm{BC}+\mathrm{Z}+\mathrm{S}+\mathrm{PL})$ & $y=0.0139 x-0.086$ & 0.9801 & $y=0.0139 x-2.145$ & 0.9848 \\
\hline $\mathrm{PFS}+(\mathrm{BC}+\mathrm{Z}+\mathrm{S}+\mathrm{SL})$ & $y=0.0139 x-0.183$ & 0.9554 & $y=0.0139 x-2.486$ & 0.9667 \\
\hline
\end{tabular}

(*) $R$ determination coefficient

$P F S$, control treatment; $P F S+(B C+Z)$, post-flotation sediment $+($ biochar + zeolite) mixture; $P F S+(B C+Z+S)$, post-flotation sediment $+($ biochar + zeolite + soil $)$ mixture; $P F S+(B C+Z+S+P L)$, post-flotation sediment + (biochar + zeolite + soil + poultry litter) mixture; $P F S+(B C+Z+S+S L)$, post-flotation sediment + (biochar + zeolite + soil + slurry) mixture willow aerial parts in the treatment modified with a mixture of biochar, zeolite, and soil $(\mathrm{BC}+\mathrm{Z}+\mathrm{S})$. Similarly to lead, the highest cadmium content was discovered in the willow biomass of the treatment where the $\mathrm{BC}+\mathrm{Z}+\mathrm{S}$ mixture was applied. The addition of $\mathrm{BC}+\mathrm{Z}+\mathrm{S}+\mathrm{PL}$ and $\mathrm{BC}+\mathrm{Z}+\mathrm{S}+\mathrm{SL}$ mixtures reduced the $\mathrm{Cd}$ content in willow biomass. The copper content in willow aerial parts did not differ significantly, except for the treatment where the $\mathrm{BC}+\mathrm{Z}+\mathrm{S}$ mixture was applied (Table 9). However, it should be emphasised that the
$\mathrm{Cu}$ contents determined in mixture-amended treatments were generally higher than in the control treatment. No significant differences were observed in the nickel content in the biomass of willow aerial parts. The Ni content in all treatments was lower than that in the control treatment.

The study by Kosowska et al. (2018) showed that the heavy metal content in plants growing on post-flotation sediment is conditioned by the available content of these elements. According to these authors, plants growing on post-flotation

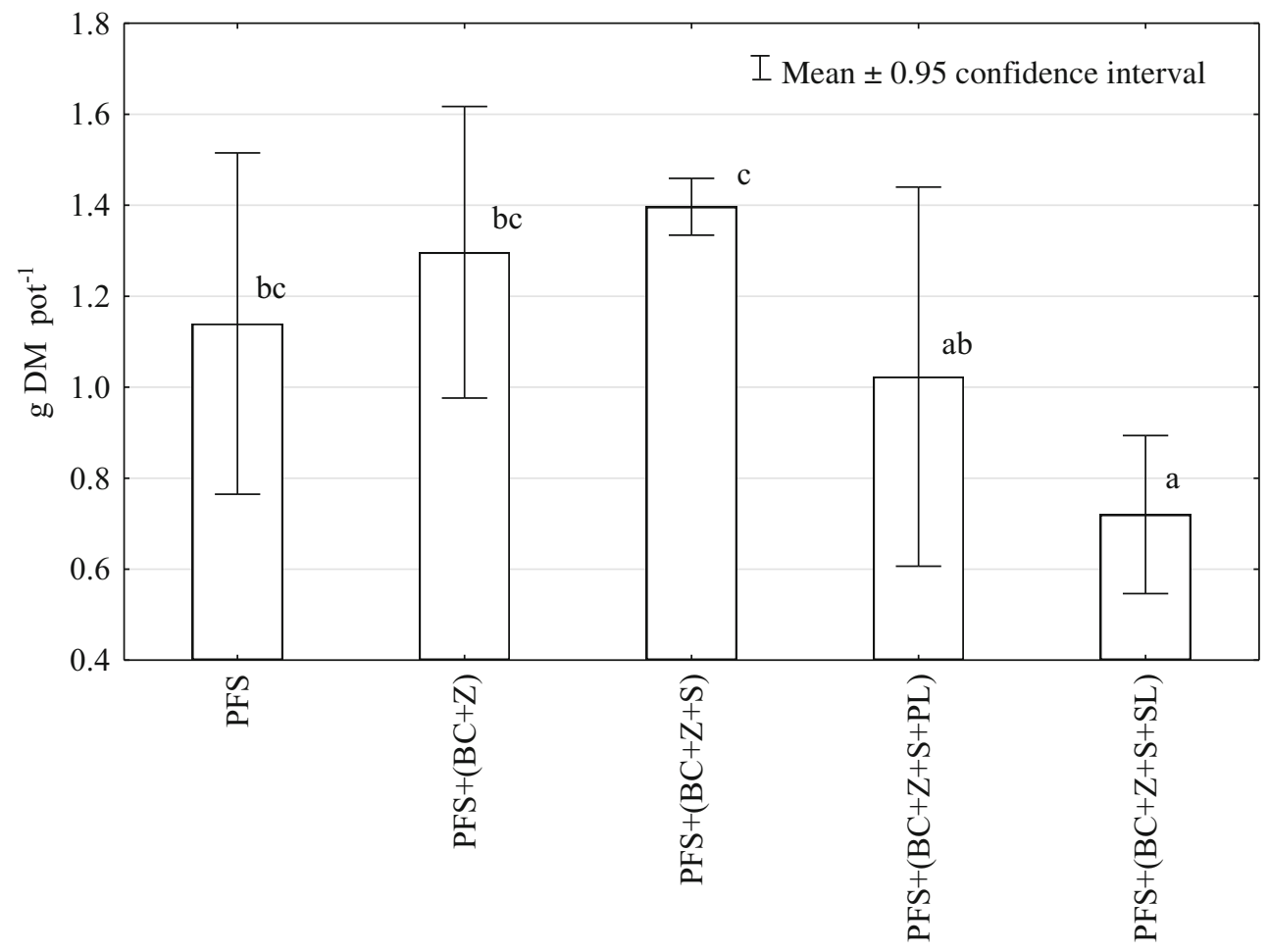

Fig. 3 The amount of willow aerial part biomass. The mean values marked with the same letters do not differ statistically significantly at $p \leq 0.05$ (according to the Tukey's test). PFS, control treatment; PFS+ $(\mathrm{BC}+\mathrm{Z})$, post-flotation sediment + (biochar + zeolite) mixture; PFS+
$(B C+Z+S)$, post-flotation sediment $+($ biochar + zeolite + soil $)$ mixture; $\mathrm{PFS}+(\mathrm{BC}+\mathrm{Z}+\mathrm{S}+\mathrm{PL})$, post-flotation sediment + (biochar + zeolite + soil + poultry litter $)$ mixture; $\mathrm{PFS}+(\mathrm{BC}+\mathrm{Z}+\mathrm{S}+\mathrm{SL})$, postflotation sediment + (biochar + zeolite + soil + slurry $)$ mixture 
Table 9 The content of heavy metals in willow aerial parts

\begin{tabular}{llllll}
\hline Treatment & $\begin{array}{l}\mathrm{Zn} \\
\mathrm{mg} \mathrm{kg}\end{array}$ & $\mathrm{Pb}$ & $\mathrm{Cd}$ & $\mathrm{Cu}$ & $\mathrm{Ni}$ \\
\hline $\mathrm{PFS}$ & $746.4 \mathrm{~b} \pm 10.5$ & $6.36 \mathrm{ab} \pm 2.62$ & $16.8 \mathrm{a} \pm 2.8$ & $17.8 \mathrm{a} \pm 2.1$ & $7.70 \mathrm{a} \pm 1.84$ \\
$\mathrm{PFS}+(\mathrm{BC}+\mathrm{Z})$ & $899.1 \mathrm{~b} \pm 19.2$ & $9.52 \mathrm{bc} \pm 2.30$ & $16.9 \mathrm{a} \pm 3.6$ & $20.8 \mathrm{a} \pm 3.0$ & $5.97 \mathrm{a} \pm 1.80$ \\
$\mathrm{PFS}+(\mathrm{BC}+\mathrm{Z}+\mathrm{S})$ & $1.341 \mathrm{c} \pm 9.5$ & $14.51 \mathrm{c} \pm 2.60$ & $27.0 \mathrm{~b} \pm 1.6$ & $30.2 \mathrm{~b} \pm 0.7$ & $7.40 \mathrm{a} \pm 0.74$ \\
$\mathrm{PFS}+(\mathrm{BC}+\mathrm{Z}+\mathrm{S}+\mathrm{PL})$ & $579.0 \mathrm{a} \pm 23.3$ & $6.37 \mathrm{ab} \pm 0.61$ & $14.2 \mathrm{a} \pm 2.5$ & $19.3 \mathrm{a} \pm 2.9$ & $6.19 \mathrm{a} \pm 1.02$ \\
$\mathrm{PFS}+(\mathrm{BC}+\mathrm{Z}+\mathrm{S}+\mathrm{SL})$ & $301.3 \mathrm{a} \pm 6.8$ & $3.59 \mathrm{a} \pm 0.89$ & $11.4 \mathrm{a} \pm 2.2$ & $15.5 \mathrm{a} \pm 1.8$ & $4.71 \mathrm{a} \pm 1.08$ \\
\hline
\end{tabular}

\pm , standard deviation; the mean values marked with the same letters do not differ statistically significantly at $\alpha \leq$ 0.05 (according to the Tukey's test)

$P F S$, control treatment; $P F S+(B C+Z)$, post-flotation sediment + (biochar + zeolite) mixture; $P F S+(B C+Z+S)$, post-flotation sediment $+($ biochar + zeolite + soil $)$ mixture; $P F S+(B C+Z+S+P L)$, post-flotation sediment + (biochar + zeolite + soil + poultry litter) mixture; $P F S+(B C+Z+S+S L)$, post-flotation sediment + (biochar + zeolite + soil + slurry) mixture sediments were enriched with $\mathrm{Cu}, \mathrm{Cd}, \mathrm{Ni}$, and $\mathrm{Pb}$. Our study revealed a significant positive relationship between the substrate $\mathrm{pH}$ and the $\mathrm{Zn}$ content $(r=0.80 ; p \leq 0.05)$ and $\mathrm{Pb}(r=$ $0.74 ; p \leq 0.74$ ) in willow aerial parts. Bearing in mind the significant $\mathrm{pH}$ effect on the content of both mobile elements in the substrate, one can conclude that there is a relationship between the discussed parameters. As argued by HanusFajerska et al. (2019), the 10-year exposure of Silene vulgaris calamine ecotype significantly increased the $\mathrm{Zn}, \mathrm{Cd}$, and $\mathrm{Pb}$ contents in both roots and aerial parts. According to their calculations, the translocation coefficient calculated after 10 years for $S$. vulgaris was the lowest for $\mathrm{Pb}(43 \%)$ and amounted to $43 \%$ for $\mathrm{Zn}$.

\section{Conclusions}

The mixtures of $\mathrm{BC}+\mathrm{Z}$ and $\mathrm{BC}+\mathrm{Z}+\mathrm{S}$ effectively reduced the content of the tested mobile heavy metals in PFS. On the other hand, $\mathrm{BC}+\mathrm{Z}+\mathrm{S}+\mathrm{PL}$ and $\mathrm{BC}+\mathrm{Z}+\mathrm{S}+\mathrm{SL}$ mixtures did not reduce heavy metal mobility in PFS. The effect of the mixtures applied to the bioavailable heavy metals content (extraction with $1 \mathrm{~mol} \mathrm{dm}^{-3} \mathrm{NH}_{4} \mathrm{NO}_{3}$ ) in PFS was comparable regardless of the element. The post-flotation sediment $\mathrm{pH}$ and EC significantly affected the content of $\mathrm{Zn}, \mathrm{Pb}, \mathrm{Cd}$, and $\mathrm{Ni}$ mobile forms. The introduction of mixtures partially composed of biologically unstable materials (poultry litter, slurry) into PFS increased the biochemical activity measured by respiratory activity and reduced biomass increment of willow aerial parts. The adverse response of willow to the introduction of mixtures with poultry litter or slurry into PFS indicates the need to verify the share of these materials in the mixtures or to stabilise them by biological or thermal processes.

Funding information The research was financed by the Ministry of Science and Higher Education of the Republic of Poland.

\section{Compliance with ethical standards}

Conflict of interest The authors declare that they have no conflict interest.

Open Access This article is licensed under a Creative Commons Attribution 4.0 International License, which permits use, sharing, adaptation, distribution and reproduction in any medium or format, as long as you give appropriate credit to the original author(s) and the source, provide a link to the Creative Commons licence, and indicate if changes were made. The images or other third party material in this article are included in the article's Creative Commons licence, unless indicated otherwise in a credit line to the material. If material is not included in the article's Creative Commons licence and your intended use is not permitted by statutory regulation or exceeds the permitted use, you will need to obtain permission directly from the copyright holder. To view a copy of this licence, visit http://creativecommons.org/licenses/by/4.0/.

\section{References}

Barrett EP, Joyner LG, Halenda PP (1951) The determination of pore volume and area distributions in porous substances II. J Am Chem Soc 73:373-380. https://doi.org/10.1021/ja01145a126

Boros-Lajszner E, Wyszkowska J, Kucharski J (2018) Use of zeolite to neutralise nikel in a soil environment. Environ Monit Assess 190(1): 1-13. https://doi.org/10.1007/s10661-017-6427-z

Brauer D, Aiken G (2006) Effects of a waste paper product on soil phosphorus, carbon, and bulk density. J Environ Qual 35(3):898-902. https://doi.org/10.2134/jeq2005.0242

Brunauer S, Emmett PH, Teller E (1938) Adsorption of gases in multimolecular layers. J Amer Chem Soc 60:309-319. https://doi.org/10. 1021/ja01269a023

Choppala GK, Bolan NS, Megharaj M, Chen Z, Naidu R (2012) The influence of biochar and black carbon on reduction and bioavailability of chromate in soils. J Environ Qual 41:1175-1184. https://doi. org/10.2134/jeq2011.0145

Ciarkowska K, Hanus-Fajerska E, Gambuś F, Muszyńska E, Czech T (2017) Phytostabilization of $\mathrm{Zn}-\mathrm{Pb}$ ore flotation tailings with Dianthus carthusianorum and Biscutella laevigata after amending with mineral fertilizers or sewage sludge. J Environ Managem 189:78-83. https://doi.org/10.1016/j.jenvman.2016.12.028 
Dubinin MM (1960) The potential theory of adsorption of gases and vapors for adsorbents with energetically nonuniform surfaces. Chem Rev 60:235-241. https://doi.org/10.1021/cr60204a006

Franus W, Wdowin M, Franus M (2014) Synthesis and characterization of zeolites prepared from industrial fly ash. Environ Monit Assessm 186:5721-5729. https://doi.org/10.1007/s10661-014-3815-5

Gondek K, Mierzwa-Hersztek M (2016) Effect of low-temperature biochar derived from pig manure and poultry litter on mobile and organic matter-bound forms of $\mathrm{Cu}, \mathrm{Cd}, \mathrm{Pb}$ and $\mathrm{Zn}$ in sandy soil. Soil Use Manag 32:357-367. https://doi.org/10.1111/sum.12285

Gul S, Naz A, Fareed I, Irshad M (2015) Reducing heavy metals extraction from contaminated soils using organic and inorganic amendments - a review. Pol J Environ Stud 24(3):1423-1426. https://doi. org/10.15244/pjoes/26970

Hanus-Fajerska E, Ciarkowska K, Muszyńska E (2019) Long-term field study on stabilization of contaminated wastes by growing clonally reproduced Silene vulgaris calamine ecotype. Plant Soil 439(1-2): 431-445

Houben D, Evrard L, Sonnet P (2013) Mobility, bioavailability and pHdependent leaching of cadmium, zinc and lead in a contaminated soil amended with biochar. Chemosphere 92:1450-1457. https:// doi.org/10.1016/j.chemosphere.2013.03.055

Jiang X, Wright AL, Wang J, Li Z (2011) Long-term tillage effects on the distribution patterns of microbial biomass and activities within soil aggregates. Catena 87:276-280. https://doi.org/10.1016/j.catena. 2011.06.011

Jindo K, Suto K, Matsumoto K, Garcia C, Sonoki T, Sanchez-Monedero MA (2012) Chemical and biochemical chracterisation of biocharblended composts prepared from poultry manure. Bioresour Technol 110:396-404. https://doi.org/10.1016/j.biortech.2012.01. 120

Kordas L, Kuc P, Lejcuś K (2018) Biological stabilisation of tailing pond coasts with use of mineral and organic substances and waterabsorbing geocomposites. Polish J Environ Stud 27(5):2089-2095

Kosowska D, Gediga K, Spiak Z (2018) Heavy metal and nutrient uptake in plants colonizing post-flotation copper tailings. Environ Sci Poll Res 25(1):824-835

Krawczyńska M, Kołwzan B, Gediga K, Dziubek A, Grabas K, Karpenko E (2015) Evaluation of the possibility of phytostabilization of post-flotation tailing ponds. Environ Protect Engineer 41(1):157-167. https://doi.org/10.5277/epe150112

Lahori AH, Mierzwa-Hersztek M, Demiraj E, Umer Sajjad R, Imran A, Shehnaz H, Aziz A, Zuberi MH, Pirzada AM, Khalid H, Zhang Z (2020) Direct and residual impacts of zeolite on the remediation of harmful elements in multiple contaminated soils using cabbage in rotation with corn. Chemosphere 250:126317. https://doi.org/10. 1016/j.chemosphere.2020.126317

Li H, Dong X, da Silva EB, de Oliveira LM, Chen Y, Ma LQ (2017) Mechanisms of metal sorption by biochars: biochar chraracteristics and modifications. Chemosphere 178:466-478. https://doi.org/10. 1016/j.chemosphere.2017.03.072

Martinez-Pagan P, Faz A, Acosta JA, Carmona DM, Martinez-Martinez S (2011) A multidisciplinary study for mining landscape reclamation: a study case on two tailing ponds in the Region of Murcia (SE Spain). Phys Chem Earth 36:1331-1344

Mierzwa-Hersztek M, Gondek K, Bajda T, Kopeć M (2019) The use of biochar and zeolite as adsorbents of mineral. Chem Industry 98(12): 1969-1972
Moreno-Barriga F, Diaz V, Acosta JA, Munoz MÁ, Faz Á, Zornoza R (2017) Organic matter dynamics, soil aggregation and microbial biomass and activity in Technosols created with metalliferous mine residues, biochar and marble waste. Geoderma 301:19-29

Ojuederie OB, Babalola OO (2017) Microbial and plant-assisted bioremediation of heavy metal polluted environments: a review. Int J. Environ Res Public Health 14(4):1504. https://doi.org/10.3390/ ijerph14121504

Okoro HK, Fatoki OS, Adekola FO, Ximba BJ, Snyman RG (2012) A review of sequential extraction procedures for heavy metals speciation in soil and sediments. Sci Rep 1(3):1-9. https://doi.org/10.4172/ scientificreports. 181

Oleszczuk N, Castro JT, da Silva MM, Korn M, Welz B, Vale MG (2007) Method development for the determination of manganese, cobalt and copper in green coffee comparing direct solid sampling electrothermal atomic absorption spectrometry and inductively coupled plasma optical emission spectrometry. Talanta 73(5):862-869. https://doi.org/10.1016/j.talanta.2007.05.005

Park JH, Choppala GK, Bolan NS, Chung JW, Chusavathi T (2011) Biochar reduces the bioavailability and phytotoxicity of heavy metals. Plant Soil 348:439-451

Porter WM, Cox W, Wilson I (1980) Soil acidity: is it a problem in Western Australia? West Aust J Agric 21:126-133

Stefaniak K, Wróżyńska M, Kroll M (2017) Application of postflotation tailings in hydroengineering structures. J Ecol Eng 18(1):113-118

Tessier A, Campbell PGC, Bisson M (1979) Sequential extraction procedure for the speciation of particulate trace metals. Anal Chem 51(7): 844-851. https://doi.org/10.1021/ac50043a017

Usman ARA, Sallam AS, Al-Omran A, El-Naggar AH, Alenazi KKH, Nadeem M, Al-Wabel MI (2013) Chemically modified biochar produced from conocarpus wastes: an efficient sorbent for $\mathrm{Fe}$ (II) removal from acidic aqueous solutions. Adsorpt Sci Technol 31: 625-640. https://doi.org/10.1260/0263-6174.31.7.625

Yuan H, Song S, An S, Liu E (2018) Ecological risk assessment of potentially toxic elements (PTEs) in the soil-pant system after reclamation of degraded sediment. Environ Sci Poll Res 25:2918129191. https://doi.org/10.1007/s11356-018-2950-x

Yuan HZ, An SQ, Zhu ZJ, Pan W (2016) Speciation and bioavailability of heavy metals in sediments taken from wetland in the Huaihe River Basin. J Environ Eng 142(9):C5015001. https://doi.org/10. 1061/(ASCE)EE.1943-7870.0000979

Zahra A, Hashmi MZ, Malik RN, Ahmed Z (2014) Enrichment and geoaccumulation of heavy metals and risk assessment of sediments of the Kurang Nallah-feeding tributary of the Rawal Lake Reservoir, Pakistan. Sci Total Environ 470-471:925-933. https://doi.org/10. 1016/j.scitotenv.2013.10.017

Zaidun SW, Jalloh MB, Awang A, Sam LM, Besar NA, Musta B, Ahmed OH, Omar L (2019) Biochar and clinoptilolite zeolite on selected chemical properties of soil cultivated with maize (Zea mays L.). Eurasian J Soil Sci 118(1):1-10

Zeien H, Brümmer GW (1989) Chemische extraction zur Bestimmung Schwermetallbindungs-formen in Böden. Mitteling Dtsch Bondenkundl Gesellsch 59(1):505-510

Publisher's note Springer Nature remains neutral with regard to jurisdictional claims in published maps and institutional affiliations. 